\title{
KULEUYEN
}

CENTER FOR ECONOMIC STUDIES

DISCUSSION PAPER SERIES DPS14.02

JANUARY 2014

The agricultural invasion and the political economy of agriculture trade policy in Belgium, 1875-1900

Maarten VAN DIJCK \& Tom TRUYTS

Public Economics

Faculty of Economics And Business 


\section{The Agricultural Invasion and the Political Economy of Agricultural Trade Policy in Belgium, 1875-1900}

Maarten Van Dijck: Flemish Heritage Agency, Koning Albert II-laan 19 bus 5, 1210 Brussels, maarten.vandijck@rwo.vlaanderen.be; and Faculty of Business Economics, University of Hasselt.

Tom Truyts: CEREC, Saint-Louis University Brussels, Boulevard du Jardin Botanique 43, 1000 Brussels, tom.truyts@fusl.ac.be; Department of Economics, University of Leuven; CORE, Université Catholique de Louvain. Tom Truyts is postdoctoral research fellow of the Fonds de la Recherche Scientifique FNRS.

\section{Acknowledgements}

We thank Erik Schokkaert, Peter Solar, Johan Swinnen, Leen Van Molle and seminar participants in Leuven, Brussels and Louvain-la-Neuve for their helpful comments. We are grateful to Niels Peeters for research assistance. 


\title{
The Agricultural Invasion and the Political Economy of
}

\section{Agricultural Trade Policy in Belgium, 1875-1900}

\begin{abstract}
After 1875, cheap grain from the United States and Russia flooded the European markets. Many countries like Germany, France, and Sweden turned to agricultural trade protection, while others, like the UK and Denmark, held on to a free trade position. Belgium adopted a middle position, leaving its grain markets open but protecting animal husbandry, dairy production, and the processing of foodstuffs. The econometric analysis of the votes of Belgian Members of Parliament on four proposals to install protectionist measures on agricultural trade seeks to identify which economic or political interests explain the Belgian policy option.
\end{abstract}

\section{Introduction}

The abolition of protectionist corn laws in all European countries, after 1846, heralded a period of agricultural free trade. By the late 1870 s, the agricultural invasion set this policy under severe pressure in most European countries. The massive import of wheat, in particular from Russia and the US, led to a price fall in these products and sparked a renewed demand for agricultural protection by corn producers. On the other hand, the industrial depression starting in the 1870s drove industrial producers to seek protection for industrial products. These elements brought, combined with local political factors such as the Kulturkampf in Germany, electoral victories to conservative political parties favouring the imposition of trade tariffs. In Germany, 
the elections of 1878 resulted in a government that imposed the protectionist tariff law of 1879. In France, the Republican government adjusted its agricultural trade policy starting from 1881 (Aldenhoff-Hübinger 2005). In 1888, after elections in 1887 installed a protectionist government, Sweden followed suit by introducing tariffs on a number of agricultural and industrial products. Also, Italy, Spain, and the AustroHungarian Empire returned to protection of their home markets. The United Kingdom and Denmark remained free trade oriented (Bairoch 1976 and 1986, Kindleberger 1978, Tracy 1989, and Irwin 1994).

The different reactions have raised questions on the determinants of agricultural tariffs in the last quarter of the nineteenth century. Interest-based explanations were explored by Cheryl Schonhardt-Bailey (1998), Sibylle Lehman (2010), and Lehman and Oliver Volckart (2011) to explain the German and Swedish return to protectionism. Kevin O'Rourke (1997) also finds many countries' reactions to the agricultural invasion consistent with an interest-based account of trade policy formation. These interest-based explanations, using the specific factors model and the Heckscher-Ohlin-Samuelson model, seem to work far better for this episode of tariff history than for the explanation of Corn Law Repeal in the United Kingdom (McKeown 1989, McLean and Bustani 1999, and Schonhardt-Bailey 2003 and 2006) and Belgium (Van Dijck and Truyts 2011) in the middle of the century.

In this article, we study the Belgian partial return to agricultural protection in the 1880 s and 1890 s as a test of interest-based explanations. Belgium is an interesting case for a number of reasons. First, Belgian tariff policy held a middle position between the countries that opted for protectionism and the countries that remained on a free trade course. Second, the Belgian economic structure was very close to the British one. The share of agriculture in GDP dropped from $37 \%$ in 1846 to $23.2 \%$ in 
1880 and $15.84 \%$ in 1895 (Goossens 1992; Blomme 1992, p. 277). Yet unlike the UK, the outcome of trade policy formation in Belgium led to some protectionist measures. Third, like in Germany, France, and Sweden, the Belgian election of 1884 brought the conservative Catholic party to power. The Liberal government was defeated after battles with the Catholic party and clergy over the position of religion in schools. This 'school war' was to some extent comparable to the Kulturkampf in Germany (Clark and Kaiser 2003). After 1884, with a clear majority in Parliament and with the agricultural interests agitating for protectionist tariffs, the conservative government only partially embraced a protectionist policy. Free trade for wheat and rye was upheld, while products from animal husbandry and food processing were protected by tariffs. Fourth, the strong statistical tradition of the country, dating back to the pioneering work of Adolphe Quetelet, provides data of exceptional quality and quantity at constituency level ('arrondissement'). This material is used to make an in depth profile of the constituencies.

We study why Belgium did not return to full-fledged agricultural protectionism after the conservative electoral victory in 1884 , but rather chose a middle position between protectionist Europe (Germany, France, Sweden) and free trade Europe (UK, Denmark). How did the agricultural invasion and the industrial crisis affect trade policy? Previous qualitative research has analysed the Belgian tariff policy (Suetens 1955, p. 110-116 and 126-135) and the position of the Catholic (Van Molle 1989 and 2008) and Socialist parties (Craeybeckx 1973 and 1974; Hüberman 2008) towards the countryside and agricultural policy, but these studies have not systematically analyzed interest-based explanations of the Belgian tariff policy. ${ }^{1}$ We study the votes of the Belgian Members of Parliament on four proposals to reinstate trade protection. In our roll-call analysis, we analyse the relative importance of personal economic interests, 
party politics, ideology, and the economic and demographic interests of Representatives' constituencies as determinants of voting.

\section{Belgium's trade policy 1875-1900}

Around 1875, the price decline of wheat and rye on the world market became tangible in Belgium (Figure 1). The average wheat price between 1860 and 1870 was 30.35 Belgian Franks for 100kg, while the five year average between 1868 and 1872 was as high as $31.6 \mathrm{fr} / 100 \mathrm{~kg}$. This dropped to a five year average around 1895 of 15.68 fr/100kg (Gadisseur 1990, p. 756-761). Likewise, the price of rye was halved. The price of meat fell with $25 \%$, and most products of animal husbandry fetched much lower prices. The agricultural interests in Belgium started to demand protectionist tariffs, a demand that became louder after the German adoption of protectionist tariffs in 1879 . With prices decreasing further at the beginning of the 1880 s and the national elections of 1884 coming closer, the cry for agricultural protection was voiced in Parliament by a number of Catholic politicians.

Figure 1: Prices and import of wheat and rye 


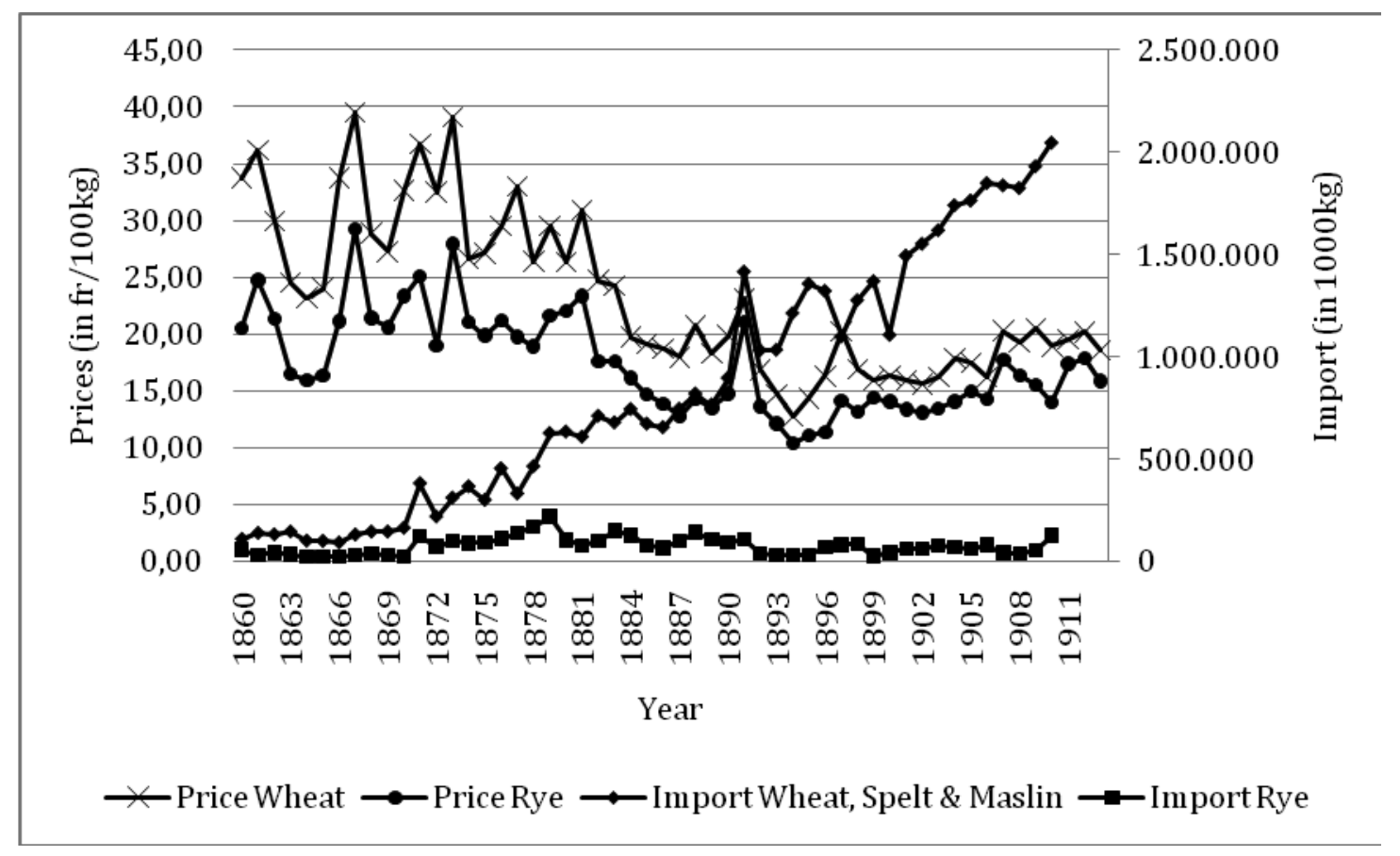

The elections of 10 June 1884 brought a large scale victory for the Catholic party. The agricultural crisis was one major election theme, but only one next to the budget, military policy, and the school war (Van Molle 1989; Lamberts and Lory 1986). The school war in particular was the major bone of contention. In 1879 and 1881 the Liberal government voted a law that extended and secularised the network of public schools. This led to a protracted polarization between Catholics and Liberals and to the foundation of a Federation of Catholic political organisations in 1884 (Wils 1986). After the electoral victory of June 1884, the Catholic party dominated Belgian Parliament up to the First World War. The Catholic government strengthend the network of Catholic schools in the subsequent years, making the polarisation of political life even stronger (Deneckere 2005, p. 477-500).

After 1884 agricultural tariffs became an issue that was discussed continuously and intensely for over a decade. In the 1830 s and 1840 s, the Catholic party had been protectionist minded, but it had left this position for a free trade stance in the $1850 \mathrm{~s}$ 
and beyond (Van Dijck 2008; Van Dijck and Truyts 2011). When agricultural prices began to drop in the 1870 s, it were Catholic party members that voiced a preference for tariffs to protect grain production and animal husbandry. The Catholic party was clearly stronger in the more rural districts in the north, while the political strongholds of the Liberals and later the Socialists were the cities and industrial centers of the provinces of Liège and Hainaut (De Smaele 2009). Yet, a substantial number of Catholic representatives, under the leadership of their prime minister August Beernaert, resisted agricultural tariffs. The majority of the Liberal representatives, and after 1894 the majority of the Socialists, defended a free trade policy (Craeybeckx 1973 and 1974; Hüberman 2008). Within a year after the election of 1884, a group of four Catholic representatives consisting of Eugène Dumont, Jules de Burlet, Léon Pastur, and Georges Snoy proposed tariffs on livestock, meat, cereals and flour. Because of the evolution of the prices, so the submitters of the bill upheld, the value of agricultural lands was declining and so were the rents. On 10 July 1885 the House of Representatives rejected the two articles contained in this bill, proposing on the one hand tariffs for cereals and on the other hand tariffs on live animals and meat (Van Molle 1989, p. 132).

A number of Catholic representatives insisted on demanding agricultural tariffs after July 1885. Dumont, de Burlet, Pastur and Snoy introduced a new bill on 15 December 1885, which was defended by a group of Catholic representatives and the Catholic minister of agriculture. However, this new bill did not include tariffs on wheat and rye. From now on the debate centered on tariffs on animals and meat. Although the Catholic prime minister, Beernaert, and a number of Catholic representatives objected tariffs for livestock and meat, this proposal eventually led to the law of 18 June 1887, which raised moderate tariffs for livestock and meat (Suetens 1955, p. 116; Van 
Molle, 1989, p. 129-133). The discussion on the bill only started in April 1887, as political life was interrupted by riots in the industrial centers in March 1886. The reaction of the police and army left 28 laborers dead. The riots had as a consequence, besides the start of a hesitating social policy, that tariffs on breadgrains could easily be depicted as a misery tax that would cause land rents to rise. This would only be in the interest of the landed classes (Suetens 1955, p. 115). After 1886 no further legislative initiative was taken to introduce taxes on basic breadgrains.

Between 1890 and 1894, different bills or amendments were introduced to expand the protectionist measures, but it never came to a vote for various political reasons (Van Molle 1989, p. 134-136). This changed after March 1894 when the free trade minded prime minister Beernaert was replaced by de Burlet, one of the architects of the protectionist proposals in 1885 and the law of 1887 after political differences in the Catholic party over the tariff question and the reform of the franchise. This and the electoral victory of October 1894 opened the way for the general tariff law of 12 July 1895.

The election of 14 October 1894 was the first election in Belgian history with general male franchise.The agricultural crisis was a major election theme because the Catholics feared that the Socialists would pilfer the farmers' votes. Both the Liberals and the Socialists sought a clear position towards the farming population (Craeybeckx 1973 and 1974). However, the Catholics secured an owerwhelming majority in 1894 (104 out of 152 seats) with a number of policy measures aimed specifically at the countryside (Van Molle 2008). The Liberals only retained 20 seats in the Lowerhouse out of 61 before the election and for the first time in Belgian history, 28 Socialist representatives entered Partliament (Luykx 1985, p. 178 and 208). 
The ensuing general tariff law of 12 July 1895 did not introduce tariffs for grain, a subject that remained taboo in Parliament, despite the Catholic farmers organisations agitating strongly for grain tariffs. Neither did it increase the tariffs on livestock and meat. The law of 1895 did introduce tariffs on cacao, canned foodstuffs, honey, fresh and dried fruits, cream and milk, gingerbread, flour, pasta, butter and margarine, a number of luxury goods (such as saffron, foie gras, and truffles), and finally one kind of cereal: oats. The law also provided protectionist tariffs for a number of textiles, clothing, tapestry, books, cast iron and ironware, musical instruments, leatherware, watches, hides, perfumes, soap, and so on (Moniteur belge 14 July 1895 , p. 25532560). The general idea of the protectionist laws of 1887 and 1895 was to orient Belgian agriculture towards the fattening up of livestock, dairy production, fruit and vegetables, and the processing of food. These products and activities were more suited to the Belgian agricultural structure, dominated by small farms, and provided for a higher added value (Van Molle 2008, p. 164).

\section{The winners and losers of free trade: research hypotheses}

Our econometric analysis understands a Member of Parliament's preferences in the votes on the two proposals of 1885 and the laws of 1887 and 1895 as a trade-off between his personal convictions and party affiliation, his personal economic interests, and the interests of his constituency, which he must serve to ensure reelection. O’Rourke 1997, Schonhardt-Bailey 1998, and Lehman 2010 have explained the typical theoretical framework, the specific factors and the Heckscher-OhlinSamuelson models, used to formulate hypotheses about the interests of the different players in the choice of trade policy. We confront this framework with the Belgian economic structure to formulate our research hypotheses. 
The specific factors model holds that labor is immobile between sectors (specific) and that therefore the workers and employers in a certain sector have the same sectoral interest. If so, then sectoral interests can be determined from trade balances. Figure 2 depicts the Belgian trade balance for the period 1860-1910 for seven goods and shows which sectors were exporting and which were import-competing. In the second half of the nineteenth century, Belgium became an importer of foodstuffs and an exporter of industrial products. The wheat producers were most severely hit by the agricultural invasion. Livestock had a small net shortage. The self-sufficiency for bread grains plummeted from $62.6 \%$ in 1880 to $27.8 \%$ in 1910 , while the self-sufficiency for meat increased from $85.4 \%$ to $95.6 \%$ (Blomme 1992, p. 282). Based on the agricultural trade balances, livestock and wheat producers would be expected to favor protectionism very strongly.

Figure 2: Trade balance 1860-1910: net export (in 1000 fr.)

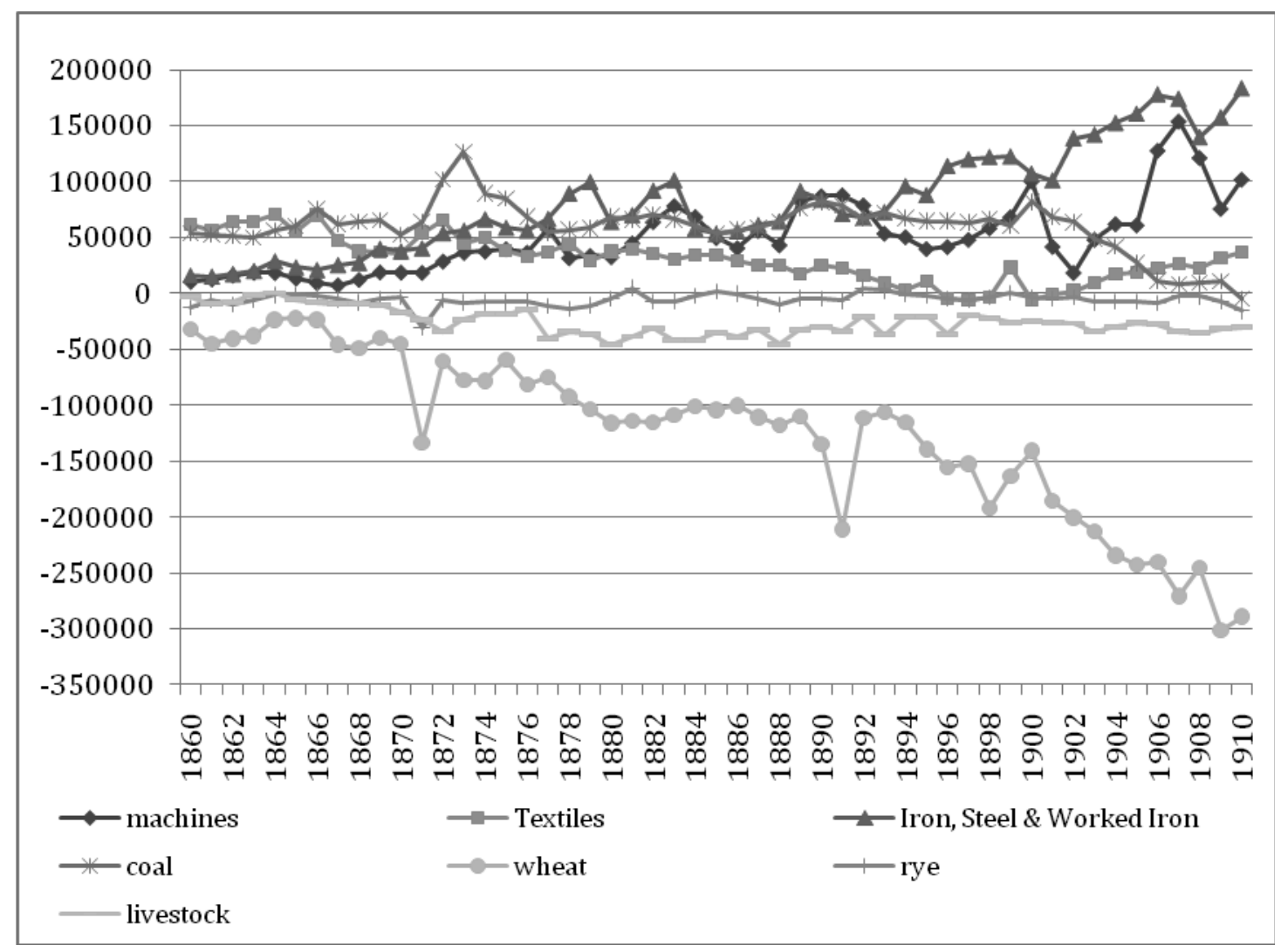


On the other hand, Figure 2 shows that Belgium had a number of strong industrial exporting sectors: machines, iron and steel, and primary products such as coal. We expect these industries to be in favor of free trade. Belgium had been strong in textiles, but this sector slowly turned from exporting to import-competing, and would therefore have shifted from a free trade position to favoring protectionism in the first five years of the $1890 \mathrm{~s}$. The recovery of the textile sector after 1895 may itself have been the result of the imposed import tariffs.

However, a number of migration researchers have shown that labor was mobile. As the wages were higher in industry, a number of land laborers migrated from the countryside to the industrial centers (Schepens 1973; Stengers 1978; Goddeeris and Hermans 2012). The development of the Belgian industrial sector meant that labor could find an alternative income outside agriculture. The absolute number of farmers remained stable around 775,000 between the middle of the century and 1896 , but the relative importance of agricultural employment dropped quickly from just under $50 \%$ in 1846 to about 25\% around 1900 (Klep 1976; Blomme 1992). After the end of the industrial crisis around 1895, the employment in the agricultural sector also descended in absolute terms (De Brabander 1983, p. 36, 46 and annex B; De Moor 2001). The number of land laborers decreased from 180,000 in 1880 to 161,000 in 1910. As this indicates a certain amount of sectoral mobility, the laborers would be expected to be in favor of free trade. This is consistent with the viewpoint of the Socialists and liberal progressivists as described by Jan Craeybeckx (1973, p. 228) and Michael Hüberman (2008).

Because labor was to a certain extent mobile, we have a closer look at the HeckscherOhlin-Samuelson model. The Heckscher-Ohlin-Samuelson model understands differences in the relative scarcity of various production factors as an important 
motivation for international trade. Countries can produce goods more cheaply when this production intensively uses relatively abundant production factors. Countries will export such goods, and import goods produced predominantly with more scarce factors. Trade thus stimulates demand for abundant production factors and reduces demand for relatively scarce factors. Therefore, trade benefits owners of the former and harms owners of the latter. We then particularly expect owners of relatively scarce production factors to request trade protection.

In Belgium capital and labor were the relatively abundant factors. Labor, being mobile, would generally be in favor of free trade. As capital was relatively abundant in Belgium, the most capital intensive heavy industries, such as coal, steel, and machine building, would be in favor of free trade. However, the position of the owners of textile companies, an activity that was much less capital intensive, is unclear.

Relatively speaking, steamships and the development of large-scale agriculture in the U.S. and Russia made land much more scarce in Belgium. Indeed, one of the main effects of the agricultural invasion was the lowering of the value and rent of land (O’Rourke 1997). In Belgium, the rents dropped in a spectacular manner between 1870 and 1895. In real terms, Belgian leases went down on average with $23 \%$ (Vanhaute 2001, p. 31 and 34). This indicates that landowners would be in favor of protection - in particular those in the constituencies with the largest share of wheat growing. We divide all constituencies into four quartiles according to the share of agricultural land used for growing wheat. Figure 3 depicts the evolution of the average lease prices of agricultural land for these four quartiles and illustrates how lease prices were higher where the land allowed for more wheat production. Most 
important for our analysis, Figure 3 shows that the decline in lease prices was the steepest in constituencies specialized in growing wheat.

Figure 3: Average lease prices of fields (quartiles in \% agricultural land for wheat in 1866)

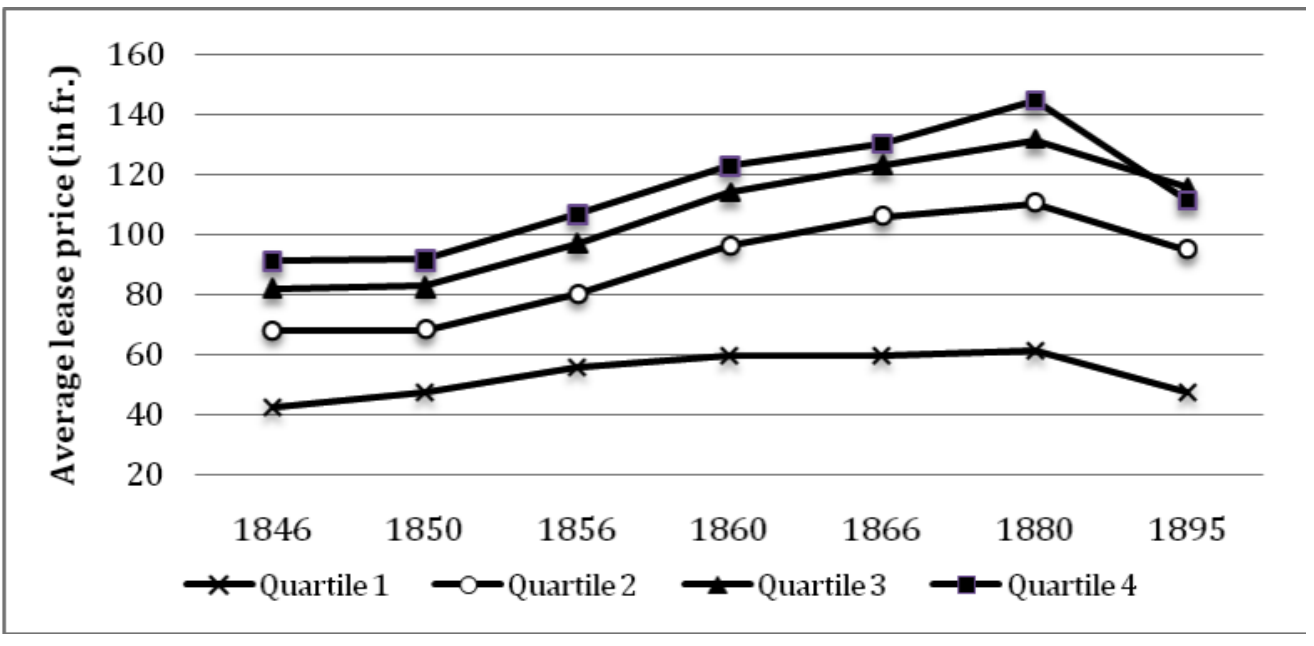

But what was the position of the small farmers who received voting rights in 1893 ? Lehman (2010, p. 151-152 and 154) and Schonhardt-Bailey (1998, p. 302) argue that the policy preference of the agricultural sector was not homogenous, but depended on farm size and specialization. It would be rational for large farms, specialized in landintensive products such as grain, to be in favor of protectionism. For small farms specialized in labor intensive products, such as fruits and vegetables, or less landintensive products, such as livestock and dairy products, it would be rational to be in favor of free trade. The Belgian agricultural structure was one of smallholdings where population pressure, the equal division of inheritances, and the division of land into smaller units by landlords accelerated the fragmentation of farms in the second half of the nineteenth century. In 1895 ca. 635,000 farms (76.5\% of all farms) were smaller than 2 hectare. Vanhaute estimated that 2 ha was the limit to make a distinction between households in which farming provided a sub-income and real commercial 
agricultural exploitations (Vanhaute 1993). In 1880, 472,000 farms were even smaller than 0.5 ha. These smallholdings produced almost exclusively for their own needs and only brought occasional surpluses to the market (Segers and Van Molle 2004, p. 56). The average farm size in Belgium was 2.3 hectare, much smaller than Denmark (14 ha), Great-Britain (12 ha), or Germany (6 ha). According to Vanhaute (2001) exploitations smaller than 20 ha accounted for two thirds of the agricultural area. It should follow from this structure that a large share of Belgian agriculture would be in favor of free trade. The country counted less than 4,000 farms that were bigger than 50 hectare. These were concentrated in the heavy clay region that ran south of Brussels from the west of the country to Liège in the east (districts of Tournai, Ath, Soignies, Nivelles, Gembloux, and Waremme). It would be expected that farmers in these districts would be in favor of protection.

\section{The Research Data}

We have collected data on Representatives' voting behavior, party affiliation, and personal economic background, as well as on the economic, demographic, and agricultural profile of their constituencies. The Representatives' votes in the four rollcall votes were collected from the published parliamentary procedures (Annales Parlementaires de la Chambre des Représentants, 10 July 1885, p. 1521-1522; 10 May 1887, p. 1091-1092, and 25 June 1895, p. 1954). We only consider votes that were actually cast, and disregard the absentees. The party affiliations of the Representatives were recovered from the main published biographical dictionaries of the Belgian Parliament (De Paepe and Raindorf-Gerard 1996; Van Molle 1972). The dummy variables CATH, LIB, and SOC indicate respectively membership of the Catholic, Liberal, and Socialist party. ${ }^{2}$ Finally, the dummy variable OTH indicates membership 
of a variety of fringe groups and independent Representatives. Figure 4 presents the party affiliation and voting behavior of the different MP's in the four successive votes. Note that, contrary to the Socialist party in 1895 , party discipline within both the Catholic and Liberal party was rather weak. In particular, the division among Catholic Representatives is a prime explanation for the two 1885 proposals being voted down.

Figure 4: Party affiliation and voting behavior in the four votes

\begin{tabular}{|l|l|l|l|l|l|l|l|l|l|l|l|l|}
\hline $1885 a$ & CATH & LIB & SOC & OTH & total & & CATH & LIB & SOC & OTH & total \\
\hline & 2 & 6 & 0 & 0 & 8 & Abstention & 0 & 0 & 0 & 0 & 0 \\
\hline Abstention & 2 & & & & & & & & & & \\
\hline
\end{tabular}

The personal interests and professional background of the Representatives were retrieved from the main biographical dictionaries of the Belgian Parliament and of other Belgian institutions (Schepens 1976; Stengers 1975; Lehoucq and Valcke 1993; Kurgan-Van Hentenrijk 1996; Caulier-Mathy 1996; De Paepe, and Raindorf-Gerard 
1996). The dummy variable PERAGT indicates personal interests in the agricultural sector as large landowner or agricultural professional. Large landownership was derived from the lists of voters eligible for the Senate. Eligibility for the Senate required a very high level of taxes paid, which could in practice only be achieved by large landowners. Furthermore, Representatives with a professional background as agricultural industrialists, traders in agricultural machinery or membership of the advisory agricultural commissions, officials of the farmers movement, and veterinaries are designated as having agricultural interests. Figure 5 depicts the overall percentage of Representatives having agricultural (and other) interests for each of the four votes. Figure 6 presents voting of Representatives with and without agricultural interests, and illustrates that Representatives with agricultural interests are more likely to support agricultural trade protections.

Figure 5: Percentage of Representatives having agricultural and other personal interests

\begin{tabular}{l|llll} 
& $1885 \mathrm{a}$ & $1885 \mathrm{~b}$ & 1887 & 1895 \\
\hline PERAGT & $35.87 \%$ & $33.98 \%$ & $34.96 \%$ & $23.24 \%$ \\
PERINDHE & $16.30 \%$ & $16.50 \%$ & $16.26 \%$ & $14.79 \%$ \\
PERINTEL & $44.57 \%$ & $47.57 \%$ & $47.15 \%$ & $52.11 \%$ \\
PERPUB & $13.04 \%$ & $17.48 \%$ & $20.33 \%$ & $13.38 \%$ \\
PERINDTE & $3.26 \%$ & $2.91 \%$ & $4.07 \%$ & $5.63 \%$
\end{tabular}

The dummy variable PERINDHE represents personal interests in the heavy industry and collects Representatives functioning as board members in the heavy industry (mining, iron and steel, machine building, glass...). The second panel of Figure 6 presents voting according to interests in the heavy industry. The dummy variable 
PERINTEL collects representatives with an explicitly intellectual professional background. This category collects teachers, university professors, scholarship commissioners, notaries, lawyers, judges, public prosecutors, journalists, writers, bankers, accountants, civil servants, medical doctors, and pharmacists. Note that for instance, industrialists may or may not have finished a higher education, but unless they also maintain any of the abovementioned positions, they are not considered to have an intellectual professional background. The third panel of Figure 6 depicts voting by intellectual profession. The dummy variable PERPUB is 1 for all representatives with a personal background in the public sector. This category comprises employees of the National Bank, teachers, university professors, mayors, judges, police commissioners, public prosecutors, and civil servants. ${ }^{3}$ The fourth panel of Figure 6 represents voting of representatives by background in the public sector. Finally, the dummy variable PERINDTE indicates personal interests in the textiles industry, and collects Representatives who owned cotton, wool or linen industries or worked as tailors. The last panel of Figure 6 represents voting of Representatives in the textiles industry.

Figure 5: Personal interests and voting
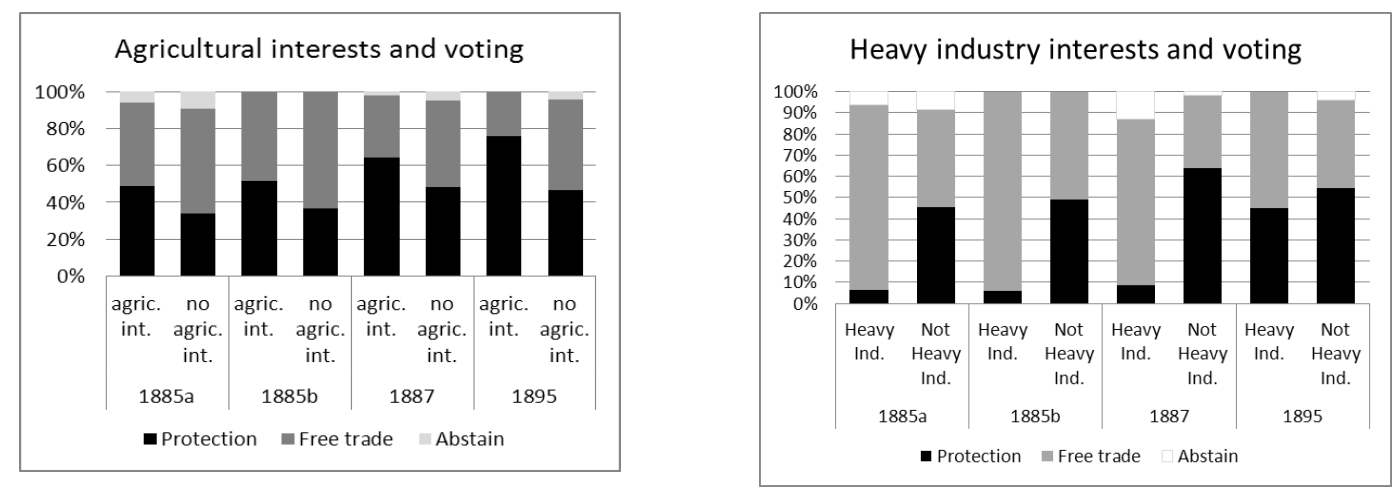

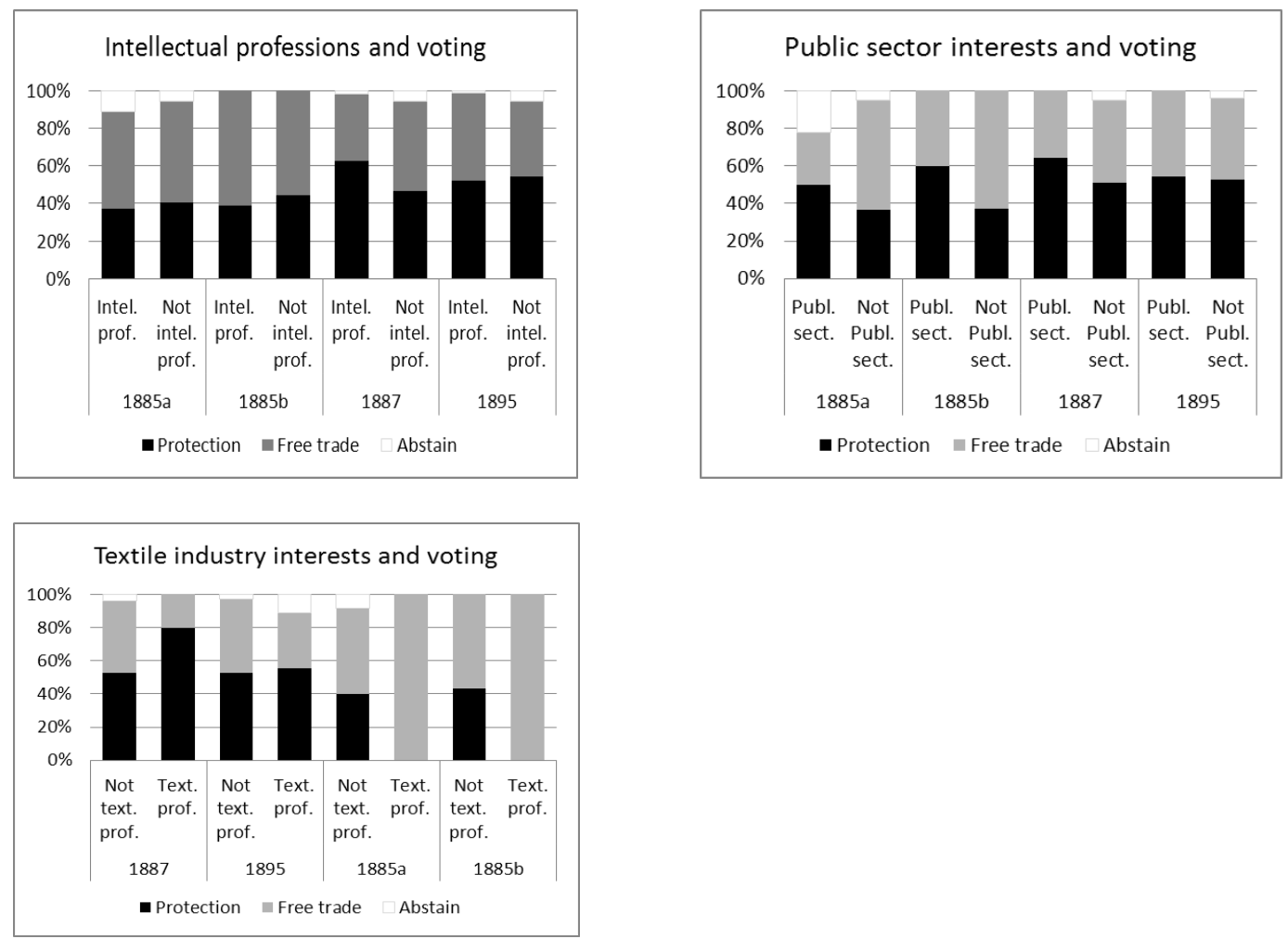

In order to identify to what extent MP's represent their constituencies' interests, we have collected data on the economic, demographic, and agricultural characteristics of their constituencies. The industrial and demographic profile of each of the 41 constituencies is reconstructed by means of the population and industrial censuses of 1890. The variable popden represents the population density of each constituency. The variable proindr represents the share of the professional population working in the heavy industry (coal, iron and steel, machines and glass). The variable protexr represents the share of the professional population working in the textiles industry. The summary statistics of these variables (unweighted for the constituencies' number of Representatives) are presented in Figure 7.

Figure 6: Descriptive statistics of the constituency variables

\begin{tabular}{l|llll} 
Variable & Mean & Std. Dev. & Min & Max \\
\hline
\end{tabular}




\begin{tabular}{l|llll}
\hline livestock (in 1885) & $53,910.28$ & $24,698.61$ & 20,568 & $12,4339.7$ \\
livestock (in 1895) & $63,008.61$ & $28,972.04$ & 22,868 & 153,959 \\
cerealr (in 1885) & 0.22 & 0.15 & 0.01 & 0.54 \\
cerealr (in 1895) & 0.20 & 0.10 & 0.02 & 0.33 \\
Popden & 2.22 & 1.51 & 0.37 & 6.53 \\
proindr & 0.05 & 0.10 & 0.00 & 0.43 \\
Protexr & 0.04 & 0.07 & 0.00 & 0.28 \\
studcatr & 0.63 & 0.21 & 0.31 & 0.96 \\
& Observations : 41 & &
\end{tabular}

The agricultural profile of each constituency is further characterized by data from the agricultural censuses of 1880 and 1895. Throughout the period 1880-1895, Belgian agriculture was rapidly changing in reaction to the agricultural invasion. For this reason, we characterize the agricultural profile of the 41 constituencies by linearly interpolating between the census data of 1880 and 1895. The variable cerealr represents the share of a constituency's agricultural surface used for growing wheat and rye. The variable livestock reflects number of cows and pigs in a constituency. Figure 7 presents the summary statistics of these variables for 1885 and 1895 . Note how the increased livestock holdings illustrate the reorientation of Belgian agriculture toward meat and dairy production. The decreased share of agricultural land used for growing wheat and rye is reinforced by a general reduction in exploited agricultural land from 2.7 million ha in 1880 to 2.6 million ha in 1895 .

To capture the importance of the school struggle as a basis of party formation and political power, we characterize the educational profile of a constituency by the variable studcatr. This variable represents the share of primary school children enlisted in Catholic schools in the constituency and was retrieved from the educational census of 1880 (Malou 1881, p. 15-16). We believe that this variable 
captures the strength of the network of Catholic organizations and the importance of Catholic opposition against the Liberal school policy in the different constituencies.

\section{Analysis of Representatives voting behavior}

In the four votes, eighteen MP's have abstained (eight for the first 1885 vote, none for the second, five in 1887, and five in 1895). We omit these abstentions from our analysis. Subsequently, the votes can be analyzed as a binary variable. We apply a probit analysis on each vote separately, to allow for maximal flexibility and to account for differences in the historical circumstances and in the voted proposals. ${ }^{4}$ Figure 8 presents the marginal effects of a probit regression at the means, while taking a Representative's party as well as personal and constituency interests into account.

Figure 7: Probit marginal effects (at the mean) with party affiliation 


\begin{tabular}{|c|c|c|c|c|}
\hline \multicolumn{5}{|c|}{ Dependent variable: Protectionist vote } \\
\hline & $1885 \mathrm{a}$ & $1885 b$ & 1887 & 1895 \\
\hline \multirow[t]{2}{*}{ LIB (d) } & $-0.97 * * *$ & $-0.94 * * *$ & $-0.97 * * *$ & $-0.54 * * *$ \\
\hline & $(0.062)$ & $(0.073)$ & $(0.041)$ & $(0.15)$ \\
\hline \multirow[t]{2}{*}{ OTH (d) } & & & $-0.57 * * *$ & \\
\hline & & & $(0.20)$ & \\
\hline \multirow[t]{2}{*}{$\mathrm{SOC}(\mathrm{d})$} & & & & $-0.58 * * *$ \\
\hline & & & & $(0.19)$ \\
\hline \multirow[t]{2}{*}{ PERAGT (d) } & 0.33 & 0.055 & 0.28 & 0.027 \\
\hline & $(0.25)$ & $(0.20)$ & $(0.18)$ & $(0.22)$ \\
\hline \multirow[t]{2}{*}{ PERINDHE (d) } & $-0.47 * *$ & $-0.60 * * *$ & -0.30 & 0.070 \\
\hline & $(0.23)$ & $(0.11)$ & $(0.31)$ & $(0.22)$ \\
\hline \multirow[t]{2}{*}{ PERINTEL (d) } & $-0.53 * *$ & $-0.49 * * *$ & 0.17 & -0.12 \\
\hline & $(0.25)$ & $(0.17)$ & $(0.19)$ & $(0.16)$ \\
\hline \multirow[t]{2}{*}{ PERPUB (d) } & $0.86 * * *$ & $0.40 * *$ & $0.34 * *$ & 0.15 \\
\hline & $(0.15)$ & $(0.20)$ & $(0.17)$ & $(0.34)$ \\
\hline \multirow[t]{2}{*}{ PERINDTE (d) } & & & $0.42 * * *$ & 0.15 \\
\hline & & & $(0.13)$ & $(0.48)$ \\
\hline \multirow[t]{2}{*}{ cerealr } & $4.70 *$ & $3.27 * *$ & $6.66^{* * *}$ & $5.81 * * *$ \\
\hline & $(2.58)$ & $(1.43)$ & $(1.71)$ & $(1.50)$ \\
\hline \multirow[t]{2}{*}{$\ln$ (livestock) } & 0.35 & $0.58 * *$ & 0.28 & -0.32 \\
\hline & $(0.38)$ & $(0.29)$ & $(0.37)$ & $(0.30)$ \\
\hline \multirow[t]{2}{*}{ popden } & $-0.45 * *$ & $-0.36 * * *$ & $-0.35 * * *$ & $-0.30 * * *$ \\
\hline & $(0.21)$ & $(0.099)$ & $(0.099)$ & $(0.068)$ \\
\hline \multirow[t]{2}{*}{ proindr } & 1.25 & $3.18^{*}$ & 0.21 & -4.45 \\
\hline & $(3.36)$ & $(1.86)$ & $(1.50)$ & $(3.11)$ \\
\hline \multirow[t]{2}{*}{ protexr } & 1.12 & $2.96^{*}$ & -0.95 & 0.89 \\
\hline & $(2.42)$ & $(1.62)$ & $(1.06)$ & (1.44) \\
\hline \multirow[t]{2}{*}{ studcatr } & $-3.39 *$ & $-2.36 * *$ & $-2.29 *$ & $-1.76^{*}$ \\
\hline & $(1.88)$ & (1.09) & $(1.28)$ & $(1.01)$ \\
\hline $\mathrm{N}$ & 81 & 92 & 123 & 141 \\
\hline pseudo R-sq & 0.75 & 0.60 & 0.71 & 0.68 \\
\hline
\end{tabular}

Marginal effects; Standard errors in parentheses

(d) for discrete change of dummy variable from 0 to 1

$* \mathrm{p}<0.10, * * \mathrm{p}<0.05, * * * \mathrm{p}<0.01$

First, party affiliation proves to be a very important predictor of voting. Keeping all else fixed at the mean, a Liberal Representative is on average respectively $97 \%$ and 
94\% less likely to support trade protection in the 1885 votes than a Catholic Representative. Likewise, the independent and Socialist MP's are both statistically and historically significantly more likely to object trade protection in all four votes than the Catholics.

Second, personal economic background is an important factor, except in 1895 . Representatives with personal interests in agriculture are consistently more likely to support protection, although this effect is never statistically significantly different from 0 at the usual confidence levels. As theory predicts, personal interests in the heavy industry decrease ceteris paribus the likelihood of a protectionist vote, although this is only significant in the two 1885 votes - in other words before the Troubles of 1886 and when only agricultural protection was at stake. MP's with an intellectual professional background seem less prone to support protectionist measures. This possibly reflects an exposure to the free trade theories of political economy during their studies, although a number of economics textbooks at for instance the University of Leuven took on a more protectionist stance in the 1890s (Erreygers and Van Dijck 2011). Representatives with a background in the public sector are, keeping all else constant, more inclined to prefer trade protection. MP's with a background in the textiles industry are more supportive of protectionist measures, but this effect is only significant in 1887.

Finally, the interests of Representatives' constituencies are reflected in their voting. A larger share of agricultural land sowed with wheat and rye increases the likelihood of a protectionist vote significantly. A greater importance of livestock increases the likelihood of a protectionist vote, and statistically significantly so in the second vote of 1885, which proposes tariffs on meat imports. A greater population density decreases on average the support for trade protection. The share of the professional 
population working in the heavy and textiles industry decreases the likelihood of a protectionist vote, although this effect disappears for textiles in the voting on the general tariff proposal of 1895 , which included a substantial package of protectionist measures on textiles. Finally, a greater share of primary school children enrolled in Catholic schools consistently decreases ceteris paribus the likelihood of a protectionist vote.

The interpretation of the coefficients in Figure 8 is somewhat confounded by the fact that the party affiliation of a constituency's Representative already represents a constituency's interests, as the constituents have likely elected a Representative which they believe best capable of serving their interests. Similarly, a Representative's choice to adhere a certain party depends on his personal economic background. Although such multicollinearity does not invalidate our results, it can make interpretation more tedious. For this reason, Figure 9 presents the marginal effects (at the mean) of a probit regression which takes only personal and constituency interests into account. $^{5}$

Figure 8: Probit marginal effects (at the mean) without party affiliation

Personal background and constituency interests

Dependent variable: Protectionist vote

\begin{tabular}{l|llll}
\hline \multicolumn{1}{c}{$1885 \mathrm{a}$} & $1885 \mathrm{~b}$ & 1887 & 1895 \\
\hline PERAGT (d) & 0.25 & 0.095 & 0.21 & 0.13 \\
PERINDHE (d) & $(0.19)$ & $(0.16)$ & $(0.13)$ & $(0.20)$ \\
PERINTEL (d) & $-0.44 * * *$ & $-0.45 * * *$ & $-0.40^{*}$ & 0.26 \\
$(0.10)$ & $(0.080)$ & $(0.21)$ & $(0.19)$ \\
& $-0.30 *$ & $-0.29 * *$ & 0.10 & -0.11 \\
& $(0.18)$ & $(0.14)$ & $(0.14)$ & $(0.14)$
\end{tabular}




\begin{tabular}{|c|c|c|c|c|}
\hline PERPUB (d) & $\begin{array}{l}0.35 \\
(0.25)\end{array}$ & $\begin{array}{l}0.17 \\
(0.17)\end{array}$ & $\begin{array}{l}0.18 \\
(0.13)\end{array}$ & $\begin{array}{l}0.37 \\
(0.28)\end{array}$ \\
\hline PERINDTE (d) & & & $\begin{array}{l}0.19 \\
(0.22)\end{array}$ & $\begin{array}{l}0.088 \\
(0.37)\end{array}$ \\
\hline cerealr & $\begin{array}{l}1.53 \\
(1.17)\end{array}$ & $\begin{array}{l}0.74 \\
(0.85)\end{array}$ & $\begin{array}{l}2.75 * * * \\
(0.82)\end{array}$ & $\begin{array}{l}4.92 * * * \\
(1.19)\end{array}$ \\
\hline $\ln ($ livestock $)$ & $\begin{array}{l}0.15 \\
(0.19)\end{array}$ & $\begin{array}{l}0.27^{*} \\
(0.16)\end{array}$ & $\begin{array}{l}0.78 * * * \\
(0.20)\end{array}$ & $\begin{array}{l}-0.13 \\
(0.20)\end{array}$ \\
\hline popden & $\begin{array}{l}-0.28 * * * \\
(0.076)\end{array}$ & $\begin{array}{l}-0.24 * * * \\
(0.055)\end{array}$ & $\begin{array}{l}-0.29 * * * \\
(0.053)\end{array}$ & $\begin{array}{l}-0.22 * * * \\
(0.049)\end{array}$ \\
\hline proindr & $\begin{array}{l}-1.29 \\
(1.48)\end{array}$ & $\begin{array}{l}0.50 \\
(1.12)\end{array}$ & $\begin{array}{l}1.31 \\
(0.86)\end{array}$ & $\begin{array}{l}-5.99 * * * \\
(1.67)\end{array}$ \\
\hline protexr & $\begin{array}{l}-2.74 * \\
(1.40)\end{array}$ & $\begin{array}{l}-0.90 \\
(0.99)\end{array}$ & $\begin{array}{l}-1.90 * * \\
(0.79)\end{array}$ & $\begin{array}{l}0.0018 \\
(1.08)\end{array}$ \\
\hline studcatr & $\begin{array}{l}-0.17 \\
(0.61)\end{array}$ & $\begin{array}{l}0.56 \\
(0.44)\end{array}$ & $\begin{array}{l}1.61 * * * \\
(0.51)\end{array}$ & $\begin{array}{l}-0.25 \\
(0.57)\end{array}$ \\
\hline $\mathrm{N}$ & 89 & 100 & 123 & 142 \\
\hline pseudo R-sq & 0.59 & 0.43 & 0.54 & 0.61 \\
\hline \multicolumn{5}{|c|}{ Marginal effects; Standard errors in parentheses } \\
\hline$* \mathrm{p}<0.10, * * \mathrm{p}<0$ & $5, * * * \mathrm{p}$ & & & \\
\hline
\end{tabular}

Note first that the effect of personal interests is less pronounced when party affiliation is not controlled for. This suggests that party formation was not so much aligned around personal interest based preferences for trade policy. It does suggest that party affiliation in itself was an important predictor of trade policy preferences, independent of personal professional background, and that personal economic interests are an important factor in explaining Representative's deviation from the party line. 
Likewise, the effects of agricultural specialization in wheat and rye and of population density is less pronounced if one does not control for party affiliation. This can again indicate that the demographic and agricultural profile of a constituency is a relatively weak predictor of its Representative's party affiliation, but that these can help to explain differences in voting within a party.

This is no longer the case for the industrial profile of a constituency, however. The effects of employment in the heavy and textiles industry is mostly more negative if one does not control for party affiliation. The main industrial centers were traditionally Liberal party strongholds, and these constituencies' preference for free trade in Figure 8 is absorbed by their Representatives' Liberal party affiliation.

Whereas the effect of the share of primary school children in Catholic schools was clearly negative if party affiliation is controlled for, this effect is mixed if the Representative's party is omitted from the analysis. Constituencies with a greater importance of Catholic primary schools are more likely to elect a Catholic Representative. But Figure 4 already showed that the Catholic party was divided on the trade policy question in a free trade and a protectionist faction. Conditional on party membership, the effect of the school war intensity was clearly negative. This can suggest that the electoral basis of Catholic Representatives could take two substitute forms: the promotion of agricultural interests and the protection of the role of religion in education and society. The negative marginal effects of studcatr in Figure 8 can mean that in constituencies where the opposition against the Liberal school policy was fierce (larger share of children in Catholic schools), Catholic Representatives could rely on average more on the protection of religion in society to ensure reelection, and were as such less inclined to stand up for the agricultural interests. 
Figure 4 shows that the division of the Catholic party between a free trade oriented faction and a protectionist faction as well as the changing balance of power between these factions are the key to understanding Belgium's change in trade policy in the 1880s and 1890s. Figure 10 illustrates the differences between the Catholic factions by depicting the conditional means of all explanatory variables, and compares these with the means in the Liberal party. In terms of personal interests, the Catholic free trade faction is clearly characterized by more outspoken heavy industry interests than the protectionist faction, and gathers, at least in 1885, more Representatives with intellectual professions. The protectionist Catholics are more prone to have personal agricultural interests and a public sector background. In terms of constituency background, the Catholic party's free trade faction clearly stems from more densely populated constituencies. This is consistent with Craeybeckx's (1973, p. 221) intuitive feeling on this divide on the Catholic side between the free trade group around prime minister Beernaert and the protectionists. In 1885, the Catholic free trade faction also still represents the textiles industry centers. Towards 1895 , the Representatives of the textiles industry centers have moved towards the protectionist faction in the Catholic party. This, in combination with the extension of voting rights, led to a shift in the balance of power within the Catholic party, making the protectionist Catholic faction sufficiently strong to pass the laws of 1887 and 1895, as illustrated in Figure 4.

Figure 9: conditional means Catholic factions and Liberals

\begin{tabular}{lllll}
$1885 \mathrm{a}$ & & $1885 \mathrm{~b}$ & \\
\hline CATH : free CATH : & CATH : free CATH : & \\
traders & protectionist LIB & traders protectionist LIB \\
\hline
\end{tabular}




\begin{tabular}{|c|c|c|c|c|c|c|}
\hline PERAGT & $28.57 \%$ & $44.44 \%$ & $35.29 \%$ & $28.57 \%$ & $42.11 \%$ & $34.29 \%$ \\
\hline PERINDHE & $19.05 \%$ & $2.78 \%$ & $26.47 \%$ & $19.05 \%$ & $2.63 \%$ & $28.57 \%$ \\
\hline PERINTEL & $61.9 \%$ & $44.44 \%$ & $44.18 \%$ & $61.9 \%$ & $47.37 \%$ & $45.71 \%$ \\
\hline PERPUB & $4.76 \%$ & $16.67 \%$ & $26.47 \%$ & $14.29 \%$ & $15.79 \%$ & $25.71 \%$ \\
\hline PERINDTE & $4.76 \%$ & - & $2.94 \%$ & $4.76 \%$ & - & $2.86 \%$ \\
\hline cerealr & $25.98 \%$ & $23.40 \%$ & $23.74 \%$ & $25.08 \%$ & $23.64 \%$ & $23.58 \%$ \\
\hline $\ln$ (livestock) & 10.76 & 11.00 & 10.88 & 10.79 & 10.98 & 10.89 \\
\hline popden & 3.14 & 1.80 & 3.39 & 3.26 & 1.87 & 3.46 \\
\hline proindr & $0.46 \%$ & $2.36 \%$ & $15.83 \%$ & $0.59 \%$ & $2.20 \%$ & $16.05 \%$ \\
\hline protexr & $7.76 \%$ & $3.13 \%$ & $5.81 \%$ & $5.93 \%$ & $4.00 \%$ & $5.66 \%$ \\
\hline \multirow[t]{4}{*}{ studcatr } & $81.54 \%$ & $66.69 \%$ & $45.94 \%$ & $79.76 \%$ & $67.86 \%$ & $45.57 \%$ \\
\hline & 1887 & & & 1895 & & \\
\hline & CATH : free & CATH : & & CATH : free & CATH : & \\
\hline & traders & protectionist & LIB & traders & protectionist & LIB \\
\hline PERAGT & $28.57 \%$ & $40.32 \%$ & $32.50 \%$ & $12.50 \%$ & $32.43 \%$ & $16.67 \%$ \\
\hline PERINDHE & $28.57 \%$ & $3.23 \%$ & $37.50 \%$ & $20.83 \%$ & $12.16 \%$ & $5.56 \%$ \\
\hline PERINTEL & $42.86 \%$ & $51.61 \%$ & $42.5 \%$ & $45.83 \%$ & $48.65 \%$ & $72.22 \%$ \\
\hline PERPUB & $14.29 \%$ & $20.97 \%$ & $22.50 \%$ & - & $13.51 \%$ & $5.56 \%$ \\
\hline PERINDTE & - & $4.84 \%$ & $2.50 \%$ & $4.17 \%$ & $6.76 \%$ & - \\
\hline cerealr & $20.57 \%$ & $25.50 \%$ & $20.31 \%$ & $24.50 \%$ & $26.16 \%$ & $13.64 \%$ \\
\hline $\ln$ (livestock) & 10.89 & 11.12 & 10.81 & 11.44 & 11.16 & 11.11 \\
\hline popden & 3.65 & 2.48 & 3.67 & 5.11 & 2.70 & 2.45 \\
\hline proindr & $3.69 \%$ & $2.38 \%$ & $18.06 \%$ & $1.01 \%$ & $0.93 \%$ & $11.47 \%$ \\
\hline protexr & $6.36 \%$ & $5.69 \%$ & $4.19 \%$ & $2.47 \%$ & $5.88 \%$ & $0.92 \%$ \\
\hline studcatr & $73.05 \%$ & $69.21 \%$ & $42.39 \%$ & $65.67 \%$ & $72.15 \%$ & $37.86 \%$ \\
\hline
\end{tabular}

\section{Conclusions}

The agricultural invasion and subsequent agricultural crisis as well as the resulting rise of protectionism in much of continental Europe, induced Belgium to a partial 
reinstallation of tariffs on imports of agricultural products. Although the conservative Catholic party held a firm majority in Parliament, it was divided on the agricultural trade issue. A Catholic free trade faction mostly collected MP's with a personal background in the heavy industry, representing on average more densely populated constituencies. The protectionist faction consisted more of Representatives with personal interests in agriculture and the public sector. In 1885, the Catholic free trade faction together with the Liberal Representatives was sufficiently large to vote down two proposals on the installation of tariffs on cereals and on meat. The workers uprising of 1886 made tariffs on bread grains politically unfeasible. As such, agricultural interests thereafter focussed their efforts on the protection of agricultural sectors which generated a higher added value and were more suited to the fragmented Belgian agricultural structure, such as livestock farming and diary production. In 1887 and 1895 , two protectionist laws were voted which installed tariffs on respectively livestock and on a broad range of products, including some agricultural products such as flour, canned products (meat, fish, vegetables and fruit), butter and margarine (excluding all cereals but oats). This move towards protection reflected the protectionist faction gaining ground within the Catholic party. Although the Catholic party was a key force in the Belgian liberalization of agricultural trade between the 1850s and 1873, it was also within this party that the agricultural interests' cry for renewed protection found the most sympathetic ears. With the extension of voting rights, the votes of the farmers became a major source of competition among the different political parties. Under these electoral pressures, the Catholic party proved most successful in building an agricultural ideology which put agriculture in the spotlight as a cornerstone of society, thus securing the farmer's votes. By the end of the nineteenth century, the Catholic party had established itself as the single protector 
of agricultural interests. The growing importance of agricultural interests in electoral terms together with the demands of the textiles industry for protection shifted the balance of power within the Catholic party and resulted in the adoption of trade protection in 1887 and 1895.

Our results also suggest that the pressures on Catholic MP's to profile themselves as defenders of agricultural interests were less pronounced in constituencies where the opposition against the Liberal school policy had been more intense and where Catholic Representatives had already built a solid electoral basis on the defence of the position of religion in education and society.

A remarkable conclusion is that interest based explanations work much better in the study of late nineteenth century agricultural trade policy in Europe than for the study of the repeal of the Corn Laws in the middle of the century. Here, it is important to take one qualitative element into consideration. The main political discussion between 1815 and 1850 was who would lose or gain from free trade in agricultural products. It was clear that the landowners would stand to lose, that industrialists would gain, but the effect on the real incomes of the laborers was much less clear. The lasting legacy of these political debates was not so much a (reversible) free trade policy, but a shared mental blueprint for the interpretation of the effects of tariffs.

\section{Appendix}

Figure 10: Probit marginal effects (at mean) with constituency interests only

Dependent variable: Protectionist vote

$\begin{array}{llll}1885 \mathrm{a} & 1885 \mathrm{~b} & 1887 & 1895\end{array}$




\begin{tabular}{|c|c|c|c|c|}
\hline cerealr & $\begin{array}{l}1.30 \\
(0.90)\end{array}$ & $\begin{array}{l}0.56 \\
(0.73)\end{array}$ & $\begin{array}{l}2.69 * * * \\
(0.76)\end{array}$ & $\begin{array}{l}4.17 * * * \\
(1.03)\end{array}$ \\
\hline $\ln$ (livestock) & $\begin{array}{l}0.018 \\
(0.15)\end{array}$ & $\begin{array}{l}0.18 \\
(0.14)\end{array}$ & $\begin{array}{l}0.78 * * * \\
(0.19)\end{array}$ & $\begin{array}{l}-0.12 \\
(0.18)\end{array}$ \\
\hline popden & $\begin{array}{l}-0.24 * * * \\
(0.052)\end{array}$ & $\begin{array}{l}-0.21 * * * \\
(0.046)\end{array}$ & $\begin{array}{l}-0.29 * * * \\
(0.048)\end{array}$ & $\begin{array}{l}-0.20 * * * \\
(0.045)\end{array}$ \\
\hline proindr & $\begin{array}{l}-2.55^{*} \\
(1.46)\end{array}$ & $\begin{array}{l}-0.33 \\
(0.95)\end{array}$ & $\begin{array}{l}1.05 \\
(0.81)\end{array}$ & $\begin{array}{l}-5.64 * * * \\
(1.37)\end{array}$ \\
\hline protexr & $\begin{array}{l}-1.82 * \\
(1.03)\end{array}$ & $\begin{array}{l}-0.80 \\
(0.83)\end{array}$ & $\begin{array}{l}-1.46 * * \\
(0.73)\end{array}$ & $\begin{array}{l}-0.16 \\
(0.88)\end{array}$ \\
\hline Studcatr & $\begin{array}{l}-0.63 \\
(0.50)\end{array}$ & $\begin{array}{l}0.19 \\
(0.38)\end{array}$ & $\begin{array}{l}1.54 * * * \\
(0.47)\end{array}$ & $\begin{array}{l}-0.038 \\
(0.51)\end{array}$ \\
\hline $\mathrm{N}$ & 92 & 103 & 123 & 142 \\
\hline pseudo R-sq & 0.48 & 0.31 & 0.48 & 0.58 \\
\hline
\end{tabular}

Marginal effects; Standard errors in parentheses

(d) for discrete change of dummy variable from 0 to 1

$* \mathrm{p}<0.10, * * \mathrm{p}<0.05, * * * \mathrm{p}<0.01$

\section{References}

Aldenhoff-Hübinger, Rita. "Deux pays, deux politiques agricoles? Le protectionnisme en France et Allemagne (1880-1914).” Histoire et Sociétés Rurales 23, no. 1 (2005): $65-87$.

Bairoch, Paul. Commerce extérieur et développement économique de l'Europe au XIXe siècle. Parijs : École des Hautes Études en Sciences Sociales, 1976.

. “European Trade Policy, 1815-1914." In The Cambridge Economic History of Europe. Volume VIII. The Industrial Economies: The Development of Economic 
and Social Policies, edited by Peter Mathias and Sidney Pollard, 1-160. Cambridge: Cambridge University Press, 1986.

Blomme, Jan. The Economic Development of Belgian Agriculture: 1880-1980. A Quantitative and Qualitative Analysis. Louvain: Leuven University Press, 1993.

Caulier-Mathy, Nicole. Le monde des parlementaires liégeois 1831-1893. Essai de socio-biographies. Brussels: Palais des Académies, 1996.

Chambre des Représentants de Belgique. Annales parlementaires. Brussels: Chambre des Représentants, parliamentary years 1885, 1887 and 1895.

Clark, Christopher, and Wolfram Kaiser, eds. Culture Wars. Secular-Catholic Conflict in Nineteenth-Century Europe. Cambridge: Cambridge University Press, 2003.

Craeybeckx, Jan. "De agrarische depressie van het einde der XIXe eeuw en de politieke strijd om de boeren." Belgisch Tijdschrift voor Nieuwste Geschiedenis 4, no. 1-2 (1973): 191-231 and 5, no. 1-2 (1974): 181-225.

De Brabander, Guido L. Regionale structuur en werkgelegenheid. Een economische en geografische studie over de Belgische lange-termijn-ontwikkeling. Brussels: Académie Royale de Belgique, 1983.

De Moor, Martina. "The occupational and geographical mobility of farm labourers in Flanders from the end of the 19th to the middle of the 20th century." In Labour and labour markets between town and countryside (Middle Ages - 19th century), edited by Bruno Blondé, Eric Vanhaute and Michèle Galand, 292-304. Turnhout: Brepols, 2001.

De Paepe, Jean-Luc and Christiane Raindorf-Gerard. Le Parlement belge 1831-1894, données biographiques. Brussels: Académie Royale de Belgique, 1996. 
De Smaele. Henk. Rechts Vlaanderen. Religie en stemgedrag in negentiende-eeuws België. Louvain, Leuven University Press, 2009.

Deneckere, Gita. "Nieuwe geschiedenis van België, 1878-1905." In Nieuwe geschiedenis van België I, 1830-1905, edited by Els Witte, Jean-Pierre Nandrin, Eliane Gubin and Gita Deneckere, 443-664. Tielt: Lannoo, 2005.

Erreygers, Guido, and Maarten Van Dijck “'A Powerful Instrument of Progress'. Economic Textbooks in Belgium." In The Economic Reader. Textbooks, Manuals and the Dissemination of the Economic Sciences during the Nineteenth and Early Twentieth Centuries, edited by Massimo M. Augello en Marco E.L. Guidi, 214-247. Londen and New York: Routledge, 2011.

Gadisseur, Jean. Histoire quantitative et développement de la Belgique au XIXe siècle. vol. IV, Ia: Le produit physique de la Belgique, 1830-1913. [...] Agriculture. Brussels: Académie Royale de Belgique, 1990.

Goddeeris, Idesbald, and Roeland Hermans, eds. Migrants flamands en Wallonie 1850-2000. Brussels: Racine, 2012.

Goossens, Martine. The Economic Development of Belgian Agriculture: A Regional Perspective, 1812-1846. Brussels: Académie Royale de Belgique, 1992.

Huberman, Michael. "Ticket to trade: Belgian labour and globalization before 1914." Economic History Review 61, no. 2 (2008): 326-359.

Irwin, Douglas A. "The Political Economy of Free Trade: Voting in the British General Election of 1906.” Journal of Law and Economics 37, no. 1 (1994): 75-108.

Kindleberger, Charles P. Economic Response. Comparative Studies in Trade, Finance and Growth. Cambridge, MA: Cambridge University Press, 1978.

Klep, Paul M. "De agrarische beroepsbevolking van de provincies Antwerpen en Brabant,1846-1910. Nieuwe evaluaties van kwantitatief historisch materiaal." 
Bijdragen tot de geschiedenis, inzonderheid van het oud hertogdom Brabant 59, (1976): 25-69.

Kurgan-Van Hentenrijk, Ginette, ed. Dictionnaire des patrons en Belgique: les hommes, les entreprises, les réseaux. Brussels: De Boeck, 1996.

Lamberts, Emiel, and Jacques Lory. 1884: un tournant politique en Belgique. De machtswisseling van 1884 in België. Brussels: FUSL, 1986.

Lehmann, Sibylle H. "The German Elections in the 1870s: Why Germany Turned from Liberalism to Protectionism.” Journal of Economic History 70, no. 1 (2010): $146-178$. , and Oliver Volckart. "The political economy of agricultural protection: Sweden 1887." European Review of Economic History 15, no. 1 (2011): 29-59.

Lehoucq, Nicole, and Tony Valcke. De fonteinen van de Oranjeberg. Politiekinstitutionele geschiedenis van de provincie Oost-Vlaanderen van 1830 tot nu. Gent: Stichting Mens en Kultuur, 1993.

Luykx, Theo, and Marc Platel. Politieke geschiedenis van België. 1 van 1789 tot 1944. Antwerpen: Kluwer Rechtswetenschappen, 1985.

Malou, Jules. Récensement de la population des écoles primaires et gardiennes au 15 décembre 1880. Brussels: Gobbaerts, 1881.

McKeown, Timothy J. "The Politics of Corn Law Repeal and Theories of Commercial Policy.” British Journal of Political Science 19, no. 3 (1989): 353-80.

McLean, Iain, and Camilla Bustani. "Irish Potatoes and British Politics: Interests, Ideology, Heresthetic, and the Repeal of the Corn Laws." Political Studies 47, no. 5 (1999): 817-36.

Moniteur belge 14 July 1895. 
O’Rourke, Kevin. “The European grain invasion.” Journal of Economic History 57, no. 4 (1997): 775-801.

Schepens Luc. Van vlaskutser tot Franschman. Bijdrage tot de geschiedenis van de Westvlaamse plattelandsbevolking in de negentiende eeuw. Brugge: Westvlaams Ekonomisch Studiebureau, 1973.

. De Provincieraad van West-Vlaanderen, vol. 1, 1836-1921. Tielt: Lannoo, 1976.

Schonhardt-Bailey, Cheryl. "Parties and Interests in the Marriage of Iron and Rye." British Journal of Political Science 28, no. 2 (1998): 291-330. . "Ideology, Party, and Interests in the British Parliament of 1841-1847." British Journal of Political Science 33, no. 4 (2003): 581-605. . From the Corn Laws to Free Trade: Interests, Ideas, and Institutions in Historical Perspective. Cambridge, MA: MIT Press, 2006.

Segers, Yves, and Leen Van Molle. Leven van het land. Boeren in België 1750-2000. Louvain: Davidsfonds, 2004.

Stengers, Jean. Index des éligibles au Sénat, 1831-1893. Brussels: Académie Royale de Belgique, 1975. . Émigration et immigration en Belgique au XIXe et au XXe siècles. Brussels: Académie Royale de Belgique, 1978.

Suetens, Max. Histoire de la politique commercial de la Belgique depuis 1830 jusqu'à nos jours. Brussels: Libraire Encyclopedie, 1955.

Tracy, Michael. Government and Agriculture in Western Europe 1880-1988. New York: Harvester Wheatsheaf, 1989. 
Van Dijck, Maarten. De wetenschap van de wetgever. De klassieke politieke economie en het Belgische landbouwbeleid, 1830-1884. Louvain: Leuven University Press, 2008.

Van Dijck, Maarten and Tom Truyts, "Ideas, Interests, and Politics in the Case of Belgian Corn Law Repeal, 1834-1873." Journal of Economic History 71, no. 1 (2011): 185-210.

Van Molle, Paul. Le Parlement Belge 1894-1972. Antwerp-Utrecht: Standaard Wetenschappelijke Uitgeverij, 1972.

Van Molle, Leen. Katholieken en landbouw. Landbouwpolitiek in België 1884-1914. Louvain: Leuven University Press, 1989. . "A State for the Peasants or the Peasants for the State? The Two Faces of Belgian Agricultural Policy, 1830-1914." In The State and Rural Societies. Policy and Education in Europe 1750-2000, edited by Nadine Vivier, 159-176. Turnhout: Brepols, 2008.

Vanhaute, Eric. "Eigendomsverhoudingen in de Belgische en Vlaamse landbouw tijdens de 18de en 19de eeuw." Belgisch Tijdschrift voor Nieuwste Geschiedenis 24, no. 1-2 (1993): 185-226.

- "Rich Agriculture and Poor Farmers: Land, Landlords and Farmers in Flanders in the Eighteenth and Nineteenth Centuries." Rural History 12, no. 1 (2001): $19-40$.

Wils, Lode. "De katholieke partij in de 19e eeuw: organisatie, programma en aanhang." In 1884: Un tournant politique en Belgique. De machtswisseling van 1884 in België, edited by Emiel Lamberts and Jacques Lory, 69-97. Brussels: FUSL, 1986. 
${ }^{1}$ We do not use the framework of King (1997) to analyse the elections of 1884, 1886 and 1894 as Lehman (2010) did. Such approach is inappropriate to our setting because the elections were dominated by several political issues and because all parties voted dividedly on the tariffs issue.

${ }^{2}$ We have also included Daens, single Representative of the Christian Workers' party in this category, because the agricultural program of Daens was highly similar to that of the Socialist party. See Craeybeckx $(1973,224)$ on this issue.

${ }^{3}$ The categories indicated by the personal background variables are not mutually exclusive. Teachers and university professors are for instance included in both PERINTEL and PERPUB, and can also be included in PERAGT, e.g. because of being large landowners.

${ }^{4}$ For the results reported in this section, we have selected the functional forms which provided the best fit to the data from the set of historically meaningful and interesting specifications and under the constraint that the reported results are robust to alterations in functional form and variable selection. ${ }^{5}$ One could argue that the personal economic background of a Representative is similarly codetermined by the interests of his constituency. However, this does not generate particular interpretation (or estimation) problems, and is not intrinsically different from multicolinearity issues at the level of constituency characteristics (for instance correlation between population density and industrialization). As a robustness check, the reader can verify in appendix that the marginal effects of a probit regression with only constituency interests do not differ much from the coefficients reported in Figure 8. 
Copyright (c) 2014 @ the author(s). Discussion papers are in draft form. This discussion paper is distributed for purposes of comment and discussion only. It may not be reproduced without permission of the copyright holder. Copies of working papers are available from the author. 